УДК 343.148

DOI https://doi.org/10.32849/2663-5313/2021.3.44

\title{
Віктор Халявка,
}

заступник директора центру - завідувач відділу автотехнічних досліджень

та криміналістичного дослідження транспортних засобів

Черкаського науково-дослідного експертно-криміналістичного иентру

Міністерства внутрішніх справ України

\section{Олександр Юрчик,}

стариий судовий експерт сектору автотехнічних досліджень

відділу автотехнічних досліджень та криміналістичного дослідження транспортних засобів

Черкаського науково-дослідного експертно-криміналістичного центру

Міністерства внутрішніх справ України

\section{ПРИЧИННИЙ ЗВ'ЯЗОК МІЖ ДІЯМИ УЧАСНИКІВ ДОРОЖНЬОГО РУХУ ТА ВИНИКНЕННЯМ ДОРОЖНЬО-ТРАНСПОРТНОЇ ПРИГОДИ}

Актуальність статті полягає в тому, що в експертній практииі під час проведення автотехнічної експертизи, за умови необхідності спечіальних пізнань, на підставі проведених досліджень експерт-автотехнік може зробити висновок про причину і необхідні умови виникнення дорожньо-транспортної пригоди та встановити причинний зв'язок між окремими обставинами події. Причина - ие явище, яке зумовлює або породжує інше явище. Причинний зв'язок - ие об'єктивний зв'язок між дією (бездіяльністю) тієї чи іншої особи і певним наслідком, до якого призвели дії иієі особи. Питання про причинний зв'язок постає, коли особа притягається до відповідальності за шкідливі наслідки ї̈ дії або бездіяльності у разі правопорушення. Якщо закон, забороняючи те чи інше діяння, пов'язує відповідальність за нього з настанням певного шкідливого наслідку, то для притягнення особи, винної у вчиненні чього діяння, до відповідальності треба, крім інших обставин, встановити і те, що до ивого наслідку призвели ї̈ дії або бездіяльність. У кримінальному праві причинний зв'язок є необхідним елементом об'єктивної сторони тих складів злочину, які містять вказівку не лише на заборонене діяння, а й на його шкідливий наслідок. Відсутність причинного зв'язку між протиправним діянням особи і певним шкідливим наслідком виключає можливість притягнення особи до відповідальності. У иивільному, трудовому, адміністративному праві обов'язок відшкодувати заподіяну шкоду також можна покласти лише на особу, діяння якої є причиною иієі шкоди. У проиесі розгляду справ, пов'язаних з порушенням правил безпеки дорожнього руху та експлуатації транспортних засобів, виникає необхідність у допомозі експерта-автотехніка, висновки якого зрештою стануть чи не найголовнішими для суду. Залучення експерта та проведення судової експертизи є однією із важливих форм використання спеціальних знань у судочинстві. Дорожньо-транспортна пригода має свої специфічні закономірності виникнення та розвитку. Основною причиною майже всіх дорожньо-транспортних пригод є порушення Правил дорожнього руху, але не завжди дані порушення можуть перебувати у причинному зв'язку з виникненням пригоди. Досить часто перед експертом-автотехніком ініціатор проведення експертизи ставить питання про причинний зв'язок між діями учасників дорожнього руху і виникненням дорожньотранспортної пригоди.

Ключові слова: учасник дорожнього руху, водій, пішохід, транспортний засіб, причина, судовий експерт, судова автотехнічна експертиза.

Постановка проблеми. В експертній практиці під час проведення автотехнічної експертизи, за умови необхідності спеціальних пізнань, на підставі проведених досліджень експерт-автотехнік може зробити висновок про причину і необхідні умови виникнення дорожньо-транспортної пригоди та встановити причинний зв'язок між окремими обставинами події.
Постановка завдання. Мета статті - оцінка причинного зв'язку між діями учасників дорожнього руху і виникненням дорожньо-транспортної пригоди експертом-автотехніком у рамках проведення судової експертизи. У процесі дослідження було розкрито поняття причинного зв'язку між діями (бездіяльністю) тієї чи іншої особи, яка є учасником дорожнього руху, і певним 
наслідком, до якого призвели ці дії. Розглянуто встановлення експертом-автотехніком обставин, які призвели до виникнення дорожньо-транспортної пригоди.

Виклад основного матеріалу. У Правилах дорожнього руху України зазначено, що дорожньо-транспортна пригода - це подія, що сталася під час руху транспортного засобу, внаслідок якої загинули або поранені люди чи завдані матеріальні збитки [6] Причиною дорожньо-транспортної пригоди є обставина, що спричинила виникнення аварійної обстановки, тобто обставина, в якій водій був позбавлений можливості запобігти події [2, с. 357] (перевищення водієм швидкості руху, несвоєчасне вжиття заходів щодо уникнення ДТП, дії пішоходів та ін.).

Дуже часто причиною виникнення дорожньо-транспортної пригоди є дії пішоходів, які своїми неправомірними діями створюють небезпеку для руху транспортного засобу. Наприклад, якщо пішохід у забороненому для переходу місці, порушуючи вимоги Правил дорожнього руху України, почав раптово перебігати проїзну частину перед самим транспортним засобом, коли водій не встигав навіть привести в дію гальма. За таких умов (коли водій позбавлений можливості запобігти наїзду) в причинному зв'язку 3 виникненням даної дорожньо-транспортної пригоди 3 технічної точки зору буде вихід пішохода на смугу руху транспортного засобу в момент, коли водій не мав технічної можливості уникнути наїзду на останнього шляхом застосування екстреного гальмування в умовах місця ДТП.

Якщо під час досліджень експертом буде встановлено, що водій транспортного засобу мав технічну можливість запобігти наїзду на пішохода шляхом своєчасного застосування екстреного гальмування в умовах місця ДТП, в причинному зв'язку з виникненням даної дорожньо-транспортної пригоди з технічної точки зору будуть невідповідність дій водія транспортного засобу вимогам Правил дорожнього руху України.

Аналізуючи вищенаведені приклади, можемо узагальнити, що необхідною умовою виникнення даної дорожньо-транспортної пригоди є обставини, які створили небезпечну обстановку. Так, однією з необхідних умов виникнення даної пригоди $є$ порушення пішоходом вимог Правил дорожнього руху України, але подія могла і не мати місця, якби водій вчасно застосував екстрене гальмування в умовах місця пригоди з метою уникнення наїзду на пішохода [2, с. 357].

В експертній практиці під час проведення автотехнічних досліджень експерт-автотех- нік вирішує питання про причинний зв'язок між діями учасників дорожнього руху та фактом виникнення дорожньо-транспортної пригоди лише у разі, коли для цього необхідні спеціальні (технічні) пізнання в галузі автотехнічних досліджень.

У деяких випадках експерт в межах своєї компетенції не може вирішити питання, які дії учасника дорожнього руху стали причиною виникнення дорожньо-транспортної пригоди. Наприклад, водій В., керуючи технічно справним автомобілем ВАЗ-2107, рухаючись по прямій ділянці дороги в задовільних дорожніх умовах, за відсутності перешкод та небезпеки для його руху допустив з'їзд з проїзної частини на узбіччя, де допустив наїзд на дерево. У даному випадку експерт не може вирішити питання про те, що знаходиться в причинному зв'язку 3 виникненням даної дорожньо-транспортної пригоди, оскільки з'їзд з проїзної частини відбувся на технічно справному транспортному засобі за відсутності зовнішніх факторів, що спонукали водія екстрено виконувати ті чи інші норми Правил дорожнього руху України, тобто розвиток ситуації повністю визначався вибраним водієм на свій розсуд рішенням та його реалізацією в робочому режимі або неспроможністю водія з тих чи інших причин виконати необхідні прийоми керування транспортним засобом (застосування під час руху неправильних прийомів керування, відсутність у особи навиків керування транспортним засобом, перебування водія в стані сп'яніння, водій під час руху відволікався від керування транспортним засобом або заснув за кермом та ін.)

Виходячи з експертної практики, розглянемо деякі випадки встановлення експертом причинного зв'язку між діями учасників дорожнього руху та фактом виникнення дорожньо-транспортної пригоди.

1. Перевищення водієм швидкості руху.

Якщо швидкість руху, яку вибрав водій транспортного засобу, не відповідала вимогам розділу 12 Правил дорожнього руху України, то таку швидкість слід вважати за перевищену.

Перевищення швидкості руху може бути у двох випадках:

- перевищення дозволеної швидкості руху, встановленої вимогами Правил дорожнього руху України на відповідній ділянці дороги;

- перевищення допустимої (безпечної) швидкості руху з урахуванням дорожньої обстановки чи технічного стану транспортного засобу.

Відповідно до вимог пункту 1.10. Правил дорожнього руху України [6]: 
- видимість у напрямку руху - максимальна відстань, на якій з місця водія можна чітко розпізнати межі елементів дороги та розміщення учасників руху, що дає змогу водієві орієнтуватися під час керування транспортним засобом, зокрема, для вибору безпечної швидкості та здійснення безпечного маневру;

- недостатня видимість - видимість дороги в напрямку руху менше 300 м у сутінках, в умовах туману, дощу, снігопаду тощо;

- обмежена оглядовість - видимість дороги в напрямку руху, яка обмежена геометричними параметрами дороги, придорожніми інженерними спорудами, насадженнями та іншими об'єктами, а також транспортними засобами;

- темна пора доби - частина доби від заходу до сходу сонця.

У темну пору доби, в умовах недостатньої видимості чи обмеженої оглядовості, водій повинен вибрати таку швидкість руху, щоб мати змогу зупинити транспортний засіб у межах видимості дороги.

Як приклад розглянемо наїзд на пішохода, що перетинав проїзну частину у невстановленому місці. На підставі проведених досліджень експерт може дати висновок про те, що перевищення водієм транспортного засобу швидкості руху перебуває в причинному зв'язку з виникненням даної дорожньо-транспортної пригоди, якщо під час руху з дозволеною (допустимою) швидкістю водій мав технічну можливість уникнути наїзду на пішохода шляхом застосування екстреного гальмування в умовах місця ДТП. Якщо ж водій транспортного засобу не матиме технічної можливості уникнути наїзду на пішохода шляхом застосування екстреного гальмування в умовах місця ДТП під час руху з дозволеною (допустимою) швидкістю руху, то невідповідність дій водія вимогам Правил дорожнього руху України (з технічної точки зору) не перебуватиме в причинному зв'язку з виникненням даної дорожньо-транспортної пригоди.

Під час проведення досліджень за фактом втрати керування транспортним засобом на ділянці дороги із закругленням експерт може зробити висновок, що причиною виникнення дорожньо-транспортної пригоди (з технічної точки зору) є перевищення водієм допустимої швидкості руху, якщо вибрана водієм швидкість руху транспортного засобу перевищувала максимально допустиму на даному закругленні дороги швидкість руху, внаслідок чого відбувається занос автомобіля.

2. Несвоєчасне вжиття заходів щодо уникнення ДТП.

У разі, якщо час з моменту виникнення небезпеки для руху до моменту спрацювання органів керування (гальм, керма) перевищує суму нормативного часу реакції водія і часу запізнювання спрацьовування органів управління, можна вважати, що водій несвоєчасно вжив заходів для уникнення події. За даних обставин експерт може зробити висновок, що в причинному зв'язку з виникненням дорожньо-транспортної пригоди (з технічної точки зору) перебувають дії водія, що не відповідають вимогам Правил дорожнього руху України, якщо буде встановлено, що за умови своєчасного вжиття заходів останній мав технічну можливість уникнути пригоди.

Як приклад розглянемо наїзд на пішохода, що перетинав проїзну частину у невстановленому місці. Водій транспортного засобу застосував гальмування, і наїзд на пішохода стався в процесі гальмування транспортного засобу. 3 одного боку, водій виконав вимоги п. 12.3. Правил дорожнього руху України, але, провівши розрахунки часу руху пішохода з моменту виникнення небезпеки для руху і до моменту наїзду, експерт встановив, що у разі своєчасного застосування гальмування водій транспортного засобу мав технічну можливість уникнути наїзду на пішохода. Отже, в діях водія вбачається невідповідність вимогам Правил дорожнього руху України, яка (з технічної точки зору) перебуває в причинному зв'язку з виникненням дорожньо-транспортної пригоди.

3. Застосування маневру замість гальмування.

Застосування маневру для запобігання дорожньо-транспортної пригоди (з технічної точки зору) слід вважати виправданим у випадках, коли водій не мав технічної можливості уникнути пригоди шляхом гальмування. В інших випадках у разі виникнення небезпеки для руху водій, відповідно до вимог Правил дорожнього руху України, зобов'язаний застосовувати гальмування.

Наприклад, у момент виходу пішохода на проїзну частину з правого узбіччя за напрямком руху транспортного засобу водій автомобіля (без вжиття заходів для зниження швидкості) виконав маневр відвороту вліво, внаслідок чого на смузі зустрічного руху (за межами небезпечної зони) стався наїзд на пішохода. Сам факт наїзду на пішохода за межами смуги руху транспортного засобу може вказувати на те, що, якби водій замість виконання маневру застосував гальмування без зміни напрямку руху, пішохід вже перебував би за межами смуги руху автомобіля і наїзд на останнього не мав би місця.

4. Застосування екстреного (різкого) гальмування.

Застосування екстреного гальмування (з доведенням коліс до блокування) не 
у всіх випадках може забезпечити можливість уникнути дорожньо-транспортної пригоди, з технічної точки зору застосовувати його доцільно лише у тих випадках, коли плавним зниженням швидкості (без блокування коліс) чи виконанням маневру уникнути пригоди вже неможливо. У Правилах дорожнього руху України (п. 12.3.) зазначено, що у разі виникнення небезпеки для руху або перешкоди, яку водій об'єктивно спроможний виявити, він повинен негайно вжити заходів для зменшення швидкості аж до зупинки транспортного засобу або безпечного для інших учасників руху об'ізду перешкоди [6].

Приклад - наїзд на пішохода, що перебуває на смузі руху транспортного засобу в нерухомому стані. Якщо під час проведення експертного дослідження буде встановлено, що в момент виявлення перешкоди для руху водій автомобіля не мав технічної можливості уникнути наїзду на пішохода шляхом застосування екстреного гальмування, але мав таку можливість шляхом виконання безпечного об'їзду перешкоди, то в діях водія автомобіля вбачається невідповідність вимогам Правил дорожнього руху України, які (з технічної точки зору) перебувають у причинному зв'язку з виникненням дорожньотранспортної пригоди.

В іншому випадку водій, наближаючись до закруглення дороги вправо, в умовах необмеженої видимості, замість поступового зниження швидкості (без блокування коліс), перед самим закругленням застосував екстрене гальмування (з блокуванням коліс), внаслідок чого допустив з'їзд некерованого транспортного засобу з проїзної частини на ліве узбіччя за напрямком свого руху. Шляхом розрахунків було встановлено, що вибрана водієм швидкість руху дозволяла безпечно проїхати дану ділянку дороги без втрати керованості транспортного засобу, тому в його діях вбачається невідповідність вимогам Правил дорожнього руху України, які (з технічної точки зору) знаходяться в причинному зв'язку з виникненням дорожньо-транспортної пригоди.

У даному випадку дії водія є невиправданими, оскільки причиною з'їзду з проїзної частини транспортного засобу був його некерований стан внаслідок блокування коліс, за якого водій не може впливати на подальший напрямок його руху.

5. Неправильний вибір безпечної дистанції.

У Правилах дорожнього руху України зазначено, що безпечна дистанція - це відстань до транспортного засобу, що рухається попереду по тій самій смузі, яка у разі його раптового гальмування або зупинки дасть можливість водієві транспортного засобу, що рухається позаду, запобігти зіткненню без здійснення будь-якого маневру [6].

Якщо при вибраній водієм дистанції він не мав технічної можливості уникнути наїзду на транспортний засіб, що рухався попереду, під час раптового його гальмування, то вибрана водієм дистанція не була безпечною, що і стало причиною дорожньо-транспортної пригоди.

У деяких випадках правильно вибрана водієм дистанція може позбавити його технічної можливості уникнути зіткнення 3 транспортним засобом, що рухається попереду, якщо раптова зупинка останнього $€$ результатом наїзду на нерухому перешкоду. За даних обставин у причинному зв'язку з виникненням пригоди буде раптова зупинка транспортного засобу, що рухався попереду, внаслідок наїзду на нерухому перешкоду. валу.

6. Неправильний вибір безпечного інтер-

У Правилах дорожнього руху України зазначено, що безпечний інтервал - це відстань між боковими частинами транспортних засобів, що рухаються, або між ними та іншими об'єктами, за якої гарантована безпека дорожнього руху [6].

Якщо водій допустив контактування транспортного засобу, його причепа, вантажу чи додаткового обладнання 3 нерухомою перешкодою під час об'їзду останньої, сам факт даної пригоди може вказувати на неправильно вибраний водієм інтервал між транспортним засобом і перешкодою, що і було причиною дорожньо-транспортної пригоди.

Якщо буде встановлено, що контактування з нерухомою перешкодою сталося внаслідок раптового бокового зсуву вантажу, то в причинному зв'язку з виникненням пригоди буде неналежне кріплення вантажу, а не недотримання водієм безпечного інтервалу.

\section{7. Створення перешкоди для руху.}

Відповідно до вимог п. 1.10. Правил дорожнього руху України «терміни, що наведені у цих Правилах», мають таке значення:

перешкода для руху - нерухомий об'єкт у межах смуги руху транспортного засобу або об'єкт, що рухається попутно в межах цієї смуги (за винятком транспортного засобу, що рухається назустріч загальному потоку транспортних засобів) і змушує водія маневрувати або зменшувати швидкість аж до зупинки транспортного засобу [6].

Перешкода для руху створюється водієм у всіх випадках, коли він своїми діями змушує інших учасників дорожнього руху 
виконувати дії з метою уникнення наїзду на перешкоду шляхом зменшення швидкості, застосування гальмування чи безпечного об'їзду [2, с. 362].

Наприклад, водій в умовах обмеженої видимості (туман) залишив транспортний засіб на проїзній частині без освітлення і не вжив заходів для його позначення. Якщо під час експертного дослідження буде встановлено, що перешкодою була створена аварійна обстановка і водій іншого транспортного засобу не мав технічної можливості уникнути наїзду на перешкоду як шляхом застосування гальмування, так і безпечного об'їзду, слід зробити висновок про те, що в причинному зв'язку з виникненням пригоди була можливість виявити перешкоду для руху на відстані, меншій за відстань, яка необхідна для зупинки транспортного засобу чи безпечного об'їзду перешкоди, тобто в діях водія, що створив перешкоду, вбачаються невідповідність вимогам Правил дорожнього руху України, яка (з технічної точки зору) знаходиться в причинному зв'язку з виникненням даної пригоди.

У разі необмеженої видимості, оглядовості та наявності у водія часу, достатнього для прийняття необхідних для уникнення наїзду або зіткнення заходів, перешкода може не створювати небезпечної обстановки.

Якщо буде встановлено, що перешкода для руху не створювала небезпечної обстановки (наявність перешкоди в умовах необмеженої видимості), тобто не примушувала водія іншого транспортного засобу вживати екстрених заходів для уникнення пригоди, експерт може зробити висновок, що дії водія, який створив перешкоду, не знаходяться в причинному зв'язку з виникненням даної дорожньо-транспортної пригоди.

7. Створення небезпеки для руху.

Відповідно до вимог п. 1.10. Правил дорожнього руху України «терміни, що наведені у цих Правилах», мають таке значення:

небезпека для руху - зміна дорожньої обстановки (у тому числі поява рухомого об'єкта, який наближається до смуги руху транспортного засобу чи перетинає іiі) або технічного стану транспортного засобу, яка загрожує безпеці дорожнього руху і змушує водія негайно зменшити швидкість або зупинитися. Окремим випадком небезпеки для руху є рух у межах смуги транспортного засобу іншого транспортного засобу назустріч загальному потоку [6].

Зазвичай небезпека для руху виникає в момент, коли відстань між транспортним засобом і перешкодою невелика, а розташування і характер руху перешкоди в даний момент може свідчити про те, що перешкода попадає в небезпечну зону або ймовірність їі попадання в зону небезпеки різко зростає.

Якщо встановлено, що водій своїми діями створив небезпеку для руху водію іншого транспортного засобу, який вже не мав можливості уникнути події, слід зробити висновок про те, що з технічної точки зору дії водія, що створив небезпеку для руху, знаходяться в причинному зв'язку з виникненням дорожньо-транспортної пригоди.

Якщо буде встановлено, що водій своїми діями створив небезпеку для руху водію іншого транспортного засобу, але останній мав технічну можливість уникнути дорожньо-транспортної пригоди, дії водія, що створив небезпеку для руху, слід розглядати як необхідну умову виникнення даної пригоди, і тому вони не відповідають вимогам Правил дорожнього руху України та знаходяться в причинному зв'язку з виникненням даної пригоди.

Недоцільно розглядати як небезпечну будь-яку дорожню обстановку, яка створюється під час руху транспортного засобу. У деяких випадках створення водієм небезпеки для руху може бути необов'язковою умовою для виникнення дорожньо-транспортної пригоди, якщо водій, якому була створена небезпека для руху, сам поставив себе в такі умови, коли виникнення пригоди буде неминучим.

Наприклад, водій, проїжджаючи нерівнозначне перехрестя, не надав переваги в русі автомобілю, що рухався по головній дорозі зі значним перевищенням дозволеної швидкості руху в населеному пункті. Якщо експертним дослідженням буде встановлено, що під час руху автомобіля (водію якого була створена небезпека) з дозволеною швидкістю руху, враховуючи час існування небезпеки для руху, водію навіть не потрібно було вживати заходів для зупинки транспортного засобу, оскільки при такій швидкості автомобіль наблизився б до перехрестя в момент, коли автомобіль, що рухався по другорядній дорозі, дане перехрестя вже би покинув. У даному випадку в діях водія, що рухався по другорядній дорозі, вбачаються невідповідності вимогам Правил дорожнього руху України, але вони не будуть перебувати в причинному зв'язку з виникненням даної пригоди.

8. Експлуатація технічно несправного транспортного засобу.

Несправний стан системи має місце, коли система не відповідає хоча б одній 3 вимог, встановлених нормативно-технічною документацією підприємства-виробника. У вимогах Правил дорожнього руху України зазначені несправності транспорт- 
ного засобу, за наявності яких його експлуатація заборонена.

Наприклад, водій, керуючи технічно несправним транспортним засобом (не спрацювання гальм задніх коліс автомобіля), допустив наїзд на пішохода. У ході експертного дослідження було встановлено, що водій не мав технічної можливості уникнути наїзду на пішохода шляхом застосування екстреного гальмування в умовах місця пригоди $з$ урахуванням технічного стану транспортного засобу та мав таку можливість у разі технічно справного транспортного засобу, тому за даних обставин у причинному зв'язку з виникненням пригоди (з технічної точки зору) буде технічний стан транспортного засобу, який не відповідав вимогам підприємства-виробника.

У даному випадку в діях водія вбачаються відповідності вимогам Правил дорожнього руху України, якщо він експлуатуе транспортний засіб з несправностями, про які йому було відомо, а також які він мав би виявити в процесі експлуатації транспортного засобу або своєчасного проведення технічного обслуговування автомобіля.

Якщо в ході експертного дослідження буде встановлено, що за відсутності несправностей водій не мав технічної можливості уникнути пригоди, технічний стан транспортного засобу не буде перебувати у причинному зв'язку з виникненням даної дорожньо-транспортної пригоди.

Якщо в ході експертного дослідження буде встановлено, що за наявності несправностей транспортного засобу водій мав технічну можливість уникнути дорожньо-транспортної пригоди, тоді в причинному зв'язку 3 виникненням останньої буде несвоєчасне вжиття водієм заходів для запобігання пригоді і технічний стан транспортного засобу не буде перебувати в причинному зв'язку з їі виникненням.

9. Причинний зв'язок між діями пішоходів і виникненням дорожньо-транспортної пригоди.

Як правило, оцінка дій пішоходів не потребує спеціальних (технічних) пізнань, і слідчий та суд самостійно можуть вирішити питання стосовно дій пішохода, їх відповідності вимогам Правил дорожнього руху України та наявності причинного зв'язку з виникненням дорожньо-транспортної пригоди. В окремих випадках для встановлення причин виникнення пригоди експертному аналізу підлягають і дії пішоходів.

Наприклад, наїзд на пішохода, який стався за межами смуги руху автомобіля внаслідок виконання водієм маневру відвороту. Якщо в ході проведення експертного дослі- дження експертом буде встановлено, що до моменту досягнення автомобілем лінії руху пішохода (без вжиття водієм заходів для зниження швидкості) останній встигав вийти за межі небезпечної зони, а тому не створював перешкоди для руху транспортного засобу, слід зробити висновок про відсутність причинного зв'язку між діями пішохода і виникненням пригоди. У даному випадку в причинному зв'язку 3 виникненням пригоди будуть дії водія, який невиправданим маневром допустив наїзд на пішохода.

Якщо експертом буде встановлено, що без вжиття водієм заходів для зменшення швидкості пішохід не встигав вийти за межі небезпечної зони, а за умови своєчасного застосування водієм екстреного гальмування пішохід виходив за межі небезпечної зони, то в даному випадку пішохід створював небезпеку для руху водію автомобіля і його дії будуть перебувати в причинному зв'язку з виникненням дорожньо-транспортної пригоди (необхідна умова виникнення даної пригоди). При цьому в діях водія автомобіля вбачаються невідповідності вимогам Правил дорожнього руху України, які також перебувають у причинному зв'язку з виникненням даної пригоди, оскільки водій, маючи можливість уникнути наїзду на пішохода шляхом своєчасного застосування екстреного гальмування в умовах місця пригоди, застосував невиправданий маневр.

У разі, коли до моменту досягнення автомобілем лінії руху пішохода останній при певній вибраній швидкості не встигав вийти за межі небезпечної зони навіть у разі своєчасного застосування водієм екстреного гальмування в умовах місця пригоди, зроблений водієм маневр був вимушеним, тому причиною дорожньо-транспортної пригоди були лише дії пішохода.

В окремому випадку експертному дослідженню підлягають дії пішохода, якщо наїзд на останнього стався на нерегульованому пішохідному переході. У Правилах дорожнього руху України (п. 18.1.) зазначено, що водій транспортного засобу, що наближається до нерегульованого пішохідного переходу, на якому перебувають пішоходи, повинен зменшити швидкість, а в разі потреби зупинитися, щоб дати дорогу пішоходам, для яких може бути створена перешкода чи небезпека [6]. Однією 3 необхідних умов даних вимог Правил дорожнього руху України є перебування пішохода на пішохідному переході. При цьому відповідно до вимог Правил дорожнього руху України (п. 4.14.) пішоходам забороняється виходити на проїзну частину, не впевнившись у відсутності небезпеки для себе та інших учасників руху, 
а також раптово виходити, вибігати на проїзну частину, в тому числі на пішохідний перехід [6].

Якщо в ході експертного дослідження буде встановлено, що пішохід раптово вийшов (вибіг) на нерегульований пішохідний перехід в момент, коли водій транспортного засобу не мав технічної можливості уникнути наїзду шляхом своєчасного застосування екстреного гальмування, то в даному випадку в причинному зв'язку з виникненням дорожньо-транспортної пригоди будуть дії пішохода.

Дуже часто у слідчих виникають питання щодо оцінки дій пішоходів, які перетинають проїзну частину по непозначеному пішохідному переходу.

У правилах дорожнього руху України зазначено, що пішохідний перехід - це ділянка проїзної частини або інженерна споруда, призначена для руху пішоходів через дорогу. Пішохідні переходи позначаються дорожніми знаками 5.35.1-5.37.2, дорожньою розміткою 1.14.1-1.14.3, пішохідними світлофорами. За відсутності дорожньої розмітки межі пішохідного переходу визначаються відстанню між дорожніми знаками або пішохідними світлофорами, а на перехресті за відсутності пішохідних світлофорів, дорожніх знаків та розмітки - шириною тротуарів чи узбіч [6]. Згідно з даним визначенням пішохідні переходи поділяються на регульовані, нерегульовані, позначені і не позначені.

У Правилах дорожнього руху України (п. 4.7.) зазначено, що пішоходи повинні переходити проїзну частину по пішохідних переходах, у тому числі підземних і надземних, а у разі їх відсутності - на перехрестях по лініях тротуарів або узбіч [6]. При цьому згідно з Правилами дорожнього руху України (п. 4.16. а) пішохід має право на перевагу під час переходу проїзної частини позначеними нерегульованими пішохідними переходами, а також регульованими переходами за наявності на те відповідного сигналу регулювальника чи світлофора [6]. Тобто у разі переходу проїзної частини на перехрестях по лініях тротуарів або узбіч (непозначеними пішохідними переходами) пішохід не має переваги в русі перед транспортними засобами. У даному випадку оцінку дій пішохода необхідно давати відповідно до дорожньої обстановки, яка склалася, на прикладах, наведених вище, а саме: експерту необхідно вирішити питання, чи створював пішохід небезпеку для руху водію транспортного засобу і чи перебувають дії пішохода в причинному зв'язку з виникненням дорожньотранспортної пригоди.

\section{Висновки}

У рамках проведення судової експертизи експерт-автотехнік може встановити причинний зв'язку між діями учасників дорожнього руху і виникненням дорожньо-транспортної пригоди.

\section{Список використаних джерел:}

1. Кристи Н.М. Методические рекомендации по производству автотехнической экспертизы. Москва: ЦНДИСЭ, 1971. 112 с.

2. Автотранспортна експертиза : підручник В.К. Доля, Ю.О. Давідіч, А.І. Лозовий та ін. Харків: ХНАМГ, 2011. 422 с

3. Судебная автотехническая экспертиза Часть II. Теоретические основы и методики экспертного исследования при производстве автотехнической экспертизы : пособие для экспертов-автотехников, следователей и судей / ответственный редактор В.А. Иларионов. Москва: ВНИИСЭ, 1980.392 с.

4. Иларионов В.А. Экспертиза дорожнотранспортных происшествий. Москва: Транспорт, 1989. 255 c.

5. Галаса П.В. Експертний аналіз дорожньотранспортних пригод: Посібник для спеціалістів та водіїв-аматорів / П.В. Галаса, В.Б. Кисельов, А.С. Куйбіда та ін.; під заг. ред. П.В. Галаси; Український центр післяаварійного захисту "ЕКСПЕРТ-СЕРВІС". Київ, 1995. 190 с.

6. Правила дорожнього руху України (зі змінами та доповненнями відповідно до постанов Кабінету Міністрів України станом на 13.05.2020). Київ, 2002

7. Дорожньо-транспортні пригоди. Критеpiї оцінювання дій водія / авт.-уклад. С.О. Шевцов, К.В. Дубонос. Харків: Факт, 2003. 176 с.

8. Дорожно-транспортные происшествия Критерии оценки действий водителя / под ред. С.О. Шевцова, К.В. Дубоноса, 2003. 257 с.

9. Применение специальных технических познаний при расследовании дорожнотранспортных происшествий. Минск, 1989. 64 с.

10. Романов Н.С. Вопросы исследования причинной связи судебной автотехнической экспертизы. Киев, 1973.60 с

11. Суворов Ю.Б. Судебная дорожно-транспортная экспертиза. Москва, 2003. 203 с.

12. Можливості використання спеціальних знань при розслідуванні дорожньо-транспортних пригод / авт.-уклад. С.О. Шевцов. Харків: СПД-ФО Мальцев О.В., 2005. 308 с. 
Viktor Khaliavka, Oleksandr Yurchyk. Causal relationships between the actions of road users and the origin of a road traffic accident

The relevance of the article is that in expert practice during the auto technical examination, provided the need for special knowledge, on the basis of research expert auto technician can make a conclusion about the cause and necessary conditions of the accident and establish a causal link between the circumstances of the event. The cause is a phenomenon that causes or generates another phenomenon. A causal relationship is an objective relationship between an action (inaction) of a person and a certain consequence to which the actions of these people have led. The question of causation arises in the case of bringing a person to justice for the harmful consequences of his actions or omissions in the offense. If the law, prohibiting an act, connects liability for it with the occurrence of a certain harmful consequence, then to bring the person guilty of this act, it is necessary to establish, among other circumstances, that this consequence was caused by his actions or omissions. In criminal law, causation is a necessary element of the objective side of those components of the crime, which contain an indication not only of the prohibited act, but also of its harmful consequences. The absence of a causal link between the wrongful act of a person and a certain harmful consequence precludes the possibility of bringing a person to justice. In civil, labor, administrative law, the obligation to compensate for the damage can also be imposed only on the person whose act is the cause of this damage. In the process of considering cases related to violations of traffic safety rules and operation of vehicles, there is a need for the assistance of an expert car mechanic, whose conclusions will eventually become the most important for the court. Involving an expert and conducting a forensic examination is one of the important forms of using special knowledge in court proceedings. A traffic accident has its own specific patterns of its origin and development. The main cause of almost all accidents is a violation of traffic rules, but these violations may not always be causally related to the accident. Quite often, the expert car technician who initiated the examination is asked about the causal link between the actions of road users and the occurrence of a traffic accident.

Key words: road user, the driver, pedestrian, vehicle, reason, forensic expert, forensic auto technical examination. 